\title{
HVMANITAS
}

\section{Poética dos sonhos e das visões em estado de vigília - II}

Autor(es): $\quad$ Pereira, Susana Marques

Publicado por: Faculdade de Letras da Universidade de Coimbra, Instituto de Estudos

URL

persistente:

Clássicos

DOI: $\quad$ DOI:http://dx.doi.org/10.14195/2183-1718_61_1

Accessed : $\quad$ 26-Apr-2023 16:04:27

A navegação consulta e descarregamento dos títulos inseridos nas Bibliotecas Digitais UC Digitalis, UC Pombalina e UC Impactum, pressupõem a aceitação plena e sem reservas dos Termos e Condições de Uso destas Bibliotecas Digitais, disponíveis em https://digitalis.uc.pt/pt-pt/termos.

Conforme exposto nos referidos Termos e Condições de Uso, o descarregamento de títulos de acesso restrito requer uma licença válida de autorização devendo o utilizador aceder ao(s) documento(s) a partir de um endereço de IP da instituição detentora da supramencionada licença.

Ao utilizador é apenas permitido o descarregamento para uso pessoal, pelo que o emprego do(s) título(s) descarregado(s) para outro fim, designadamente comercial, carece de autorização do respetivo autor ou editor da obra.

Na medida em que todas as obras da UC Digitalis se encontram protegidas pelo Código do Direito de Autor e Direitos Conexos e demais legislação aplicável, toda a cópia, parcial ou total, deste documento, nos casos em que é legalmente admitida, deverá conter ou fazer-se acompanhar por este aviso.

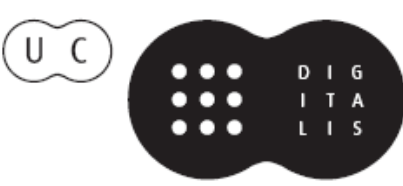


humanitas

\section{Vol. LXI}

IMPRENSA DA UNIVERSIDADE DE COIMBRA

COIMBRA UNIVERSITY PRESS 


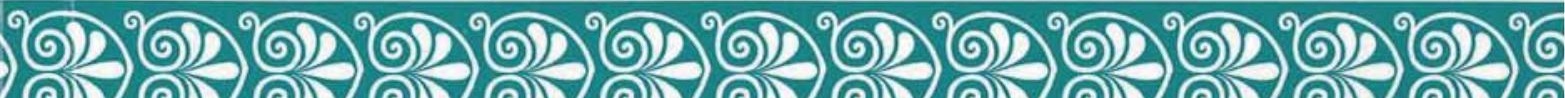

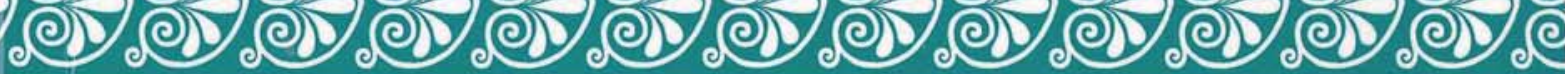

Vol. LXI 


\title{
POÉTICA DOS SONHOS E DAS VISÕES EM ESTADO DE VIGÍLIA - II ${ }^{1}$
}

\author{
Susana Marques Pereira \\ Universidade de Coimbra \\ smp@fl.uc.pt
}

\section{Resumo}

As visões em estado de vigília e, particularmente, os sonhos foram-se revestindo de uma ambiguidade progressiva, evidenciada também a nível estilístico, desde a épica homérica, até à comédia aristofânica.

No presente artigo, aborda-se de modo particular a questão da interpretação dos sonhos e das visões, bem como a reacção humana a tais fenómenos.

Palavras-chave: capacidade interpretativa, reacção humana.

\section{Abstract}

Visions in the awakening state and particularly dreams have become increasingly ambiguous over time, as attested also by stylistics, from the Homeric epic to the Aristhopanic comedy.

In the current article particular emphasis is given to the subject of the interpretation of dreams and visions as well as to the human reaction to such phenomena.

Keywords: the ability of interpretation, human reaction.

A recorrente linguagem enigmática dos sonhos e das visões em estado de vigília, na historiografia herodotiana, como na tragédia ática ou na comédia aristofânica, requer uma descodificação que a formulação, por hábito

${ }^{1} \mathrm{O}$ presente artigo dá continuidade ao texto apresentado na Humanitas 60 (2008) 11-28. 
clara, das experiências épicas costuma dispensar, uma vez que o próprio receptor parece capaz de compreender aquilo que observa e ouve. Todavia, os Poemas Homéricos fazem já alusão à classe dos intérpretes de sonhos (cf.

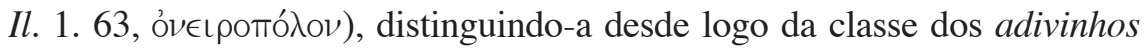

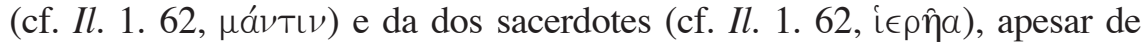
considerarem que todas elas são capazes de interpretar mensagens divinas: na opinião de Aquiles, qualquer elemento de um destes grupos está apto a esclarecer o motivo da ira de Apolo contra os Aqueus. O canto V da Ilíada menciona ainda um ỏveı рото́́ a quem não foi possível interpretar sonhos relacionados com os próprios filhos antes de estes partirem para a refrega contra os Gregos, que lhes seria

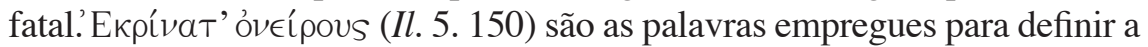
actividade do velho intérprete, que encontram paralelo no verbo usado por Penélope para se referir à decifração do sonho que a perturba (Od. 19. 535, 555), iто́крıval. A propósito deste termo, J. Russo ${ }^{2}$ regista que ele geralmente indica uma resposta explicativa de um oráculo ou de um presságio, pelo que se enquadra com oportunidade na noção de explicitar um sonho.

Píndaro parece sobrepor às ideias de intérprete e de interpretação de sonhos e visões a confirmação relativa ao conteúdo dos mesmos através de oráculos (P. 4.163 sqq., $O .8 .36$ sqq., 13. 75 sqq.), excepto quando a figura da aparição é Zeus em pessoa ( $N$. 10. 79 sqq.), pelo que é natural que linguagem onírica e oracular acabem por se fundir nas suas odes $(O .13$.

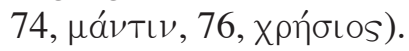

Nas Histórias, é frequente não só a consulta a figuras habilitadas para esclarecer o sentido das visões, sobretudo daquelas que são sonhadas, como também a referência à interpretação do próprio receptor sobre a mensagem, em particular sobre aquela que resulta de uma experiência oní-

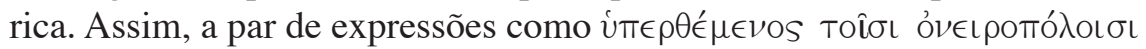

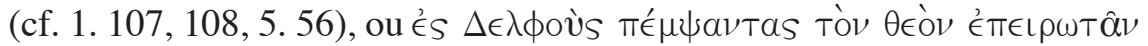

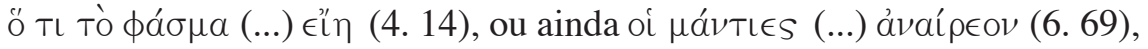
surgem outras, denunciadoras das reflexões do receptor perante o confronto

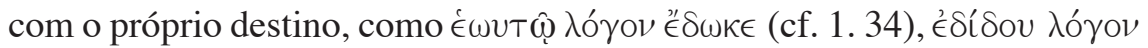

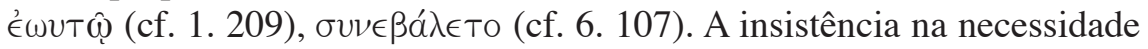
de o sonhador meditar sobre a sua experiência onírica reflecte a maior complexidade alcançada pelos sonhos em relação à tradição épica, para lá de destacar o elemento humano, em detrimento do divino.

2 1985: 255, comm. ad 555. 
A comédia aristofânica dá também testemunho da decifração da linguagem sonhada, mas sobretudo para obter motivo de cómico, propósito que o facto de os intérpretes serem homens comuns, como os servos de Vespas ou Estrepsíades de Nuvens, parece desde logo satisfazer. O emprego, digno de nota, do advérbio $\sigma o \phi \hat{s}$, ao lado de uma expressão convencional

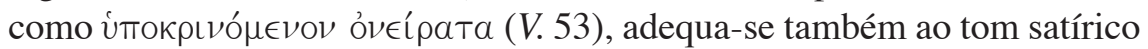
da comédia, sobretudo se tivermos em conta que os sonhos trágicos, parodiados com especial empenho por aquele género literário, nem sempre eram interpretados de forma hábil e eficaz.

Na verdade, a tragédia acentua por hábito a inacessibilidade dos mortais ao conhecimento dos desígnios do mundo transcendente, pelo que os sonhos não são por norma decifrados com eficiência, seja pelos próprios receptores, seja por figuras especializadas.

Nos Persas, Atossa, confrontada com as notícias desastrosas sobre o destino das tropas de Xerxes em terras da Hélade (249 sqq.), reconhece a ligeireza da interpretação dada à sua experiência onírica pelo coro de

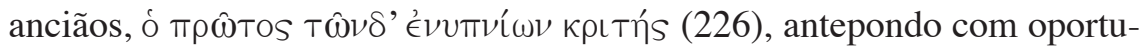

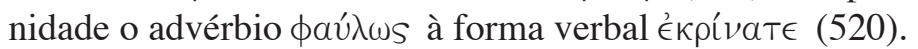

Ínaco, na condição de mortal incapaz de discernir o significado das visões sonhadas de Io (cf. A., Pr.), procura entendê-las através do recurso a um outro sinal divino, o oráculo, combinação que se reflecte em termos de linguagem, à semelhança do que acontece em Píndaro (A., Pr. 658 sqq.).

Nas Coéforas, Clitemnestra recorre à autoridade interpretativa dos

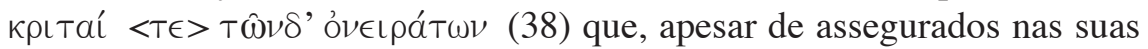
convicções pela garantia dos deuses (39), se mostram todavia inábeis, dada a sua falta de omnisciência em relação ao regresso de Orestes a Argos, para descodificar a experiência da rainha em todas as suas implicações. A interpretação eficaz do sonho acaba por ser feita pelo filho de Agamémnon,

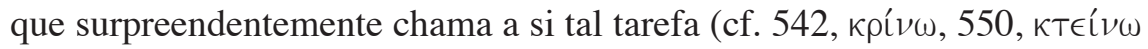

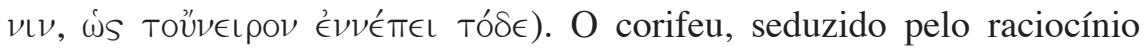
brilhante com que o jovem príncipe clarifica as imagens do sonho, consi-

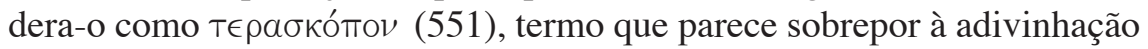
usual relacionada com experiências daquele tipo ${ }^{3}$ uma análise clarividente dos elementos por parte da personagem que é, em simultâneo, decifradora e agente das indicações oníricas.

${ }^{3}$ Cf. o emprego recorrente de vocábulos associados a $\mu a ́ v T ı S$. 
Na Electra sofocliana, mais do que 'explicar à letra' a experiência de Clitemnestra, interessa destacá-la enquanto sinal pressago para a assassina de Agamémnon, pelo que é natural a ausência de termos alusivos à interpretação onírica e a preferência por palavras legitimadoras da vingança desejada por Electra, ora evocativas do crime sanguinário da rainha (cf. 441,

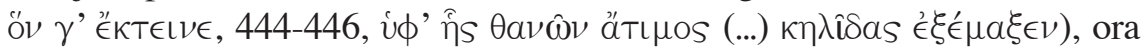

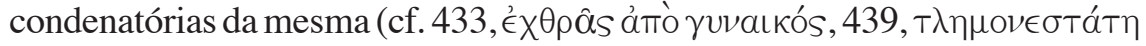

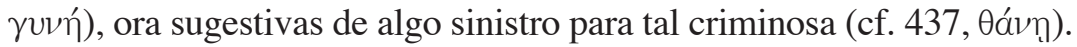

A Hécuba de Eurípides, por seu turno, menciona dois intérpretes particularmente credenciados, Heleno e Cassandra, que a angustiada rainha troiana gostaria de encontrar, $\ddot{s}_{s}(. ..) \kappa \rho i ́ v \omega \sigma \iota \nu$ ỏveí pous (89).

No caso das Euménides de Ésquilo, não se justifica o apelo a intérpretes, dado que o carácter divino das sonhadoras lhes confere uma sabedoria natural para perceber a experiência que as perturba, permitindolhes inclusive manter a mesma linguagem do sonho, retirada da actividade venatória, no diálogo que travam depois de acordar (A., Eu. 147-148).

Se o estatuto das Erínias fundamenta a sua clarividência, já a natureza humana de Ifigénia a instiga a procurar ela mesma um sentido para o sonho

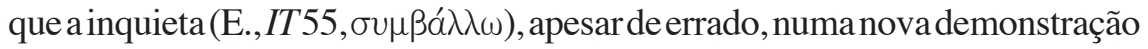
de que o confronto do ser humano com a linguagem enigmática, alusiva ao próprio destino ou ao de seres que lhe são próximos, o incita à reflexão.

$\mathrm{O}$ auriga de Reso, por sua vez, não tem sequer tempo para tentar decifrar os símbolos sonhados, porque mal desperta do sono depara-se com um espectáculo terrível de sangue e de morte, representativo afinal da concretização da experiência onírica (E., $R h$.).

À inabilidade habitual dos mortais para entender os sinais oníricos contrapõe-se a perspicácia de Cassandra, vidente credenciada para interpretar os enigmas das visões em estado de vigília que a atormentam, aliás como ela própria explica ao coro no Agamémnon, certificando-o de que deixará de instruí-lo através de uma linguagem obscura e envolta em véus (A., Ag. 1178 sqq.).

O espectro de Dario nos Persas exibe também uma sabedoria superior à do ser humano comum, embora a um nível distinto do de Cassandra ${ }^{4}$. A

${ }^{4}$ Se o discurso da vidente resulta da inspiração directa do próprio Apolo, a intervenção de Dario assenta sobretudo no ascendente supra-humano que a morte lhe concedeu, ao qual decerto deve somar-se a sua experiência paradigmática enquanto rei dos Persas. 
voz autorizada do monarca defunto não apenas esclarece os anciãos e Atossa através de um diálogo formulado em termos concretos e perceptíveis, como ainda lhes dá avisados conselhos, reflectidos na expressão insistente da ordem (cf. 824, 830, 834, 837, 840).

Infelizmente, a clarividência de Dario não é perceptível em Penteu nem nas ménades tebanas das Bacantes, que confundem fantasia e realidade, tomando as aparências como verdades que impossibilitam o conhecimento efectivo, de resto como Ájax (S., Aj. 43, 51 sqq.) e Héracles (E., HF 947 sqq.). Verbos e expressões tradutores de ilusão (S., Aj. 43, 56; E., HF 967,

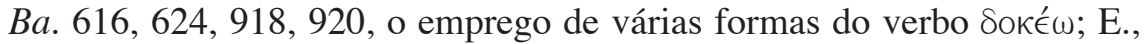

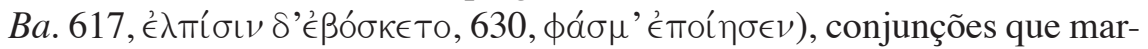
cam a negação de acontecimentos considerados como reais pelos receptores (cf. S., Aj. 64; E., $H F$ 947, Ba. 617), comparações ilustrativas da natureza fictícia das imagens observadas (cf. S., Aj. 64; E., $H F$ 949, 998, $B a .624,627,631)$ assinalam, em termos linguísticos, o costumado entendimento superficial que o homem tem do mundo, assente no primado dos sentidos e ofuscador da sabedoria genuína.

Orestes, por sua vez, em Ésquilo como em Eurípides, afigura-se com capacidade para dar uma interpretação eficaz às suas visões, encarando-as como um sinal punitivo pelo matricídio que cometera. Nas Coéforas, a pena enquadra-se na sucessão crime-culpa-castigo que envolve toda a Oresteia, pelo que é natural que o assassino seja atormentado pelas cadelas irritadas (1054) da mãe: ao contrário do que o corifeu julga na sua falta de perspicácia, a visão das divindades aterradoras não é uma mera fantasia (1051) para o receptor, resultante da perturbação após o homicídio, mas antes uma consequência efectiva do acto realizado, como ele próprio evidencia pela repetição da palavra $\delta o ́ \xi \alpha$, precedida sintomaticamente da negativa oủk, bem como pelo emprego reiterado do verbo ópá $\omega$, ora acompanhado de oủx, ora sozinho (cf. 1053-1054, 1061-1062). No Orestes, a auto-censura pelo matricídio imprime à visão inquietante das Erínias características de uma abordagem psicológica: a consciencialização da falta cometida leva o filho de Agamémnon a reconhecer a própria $\sigma u ́ v \in \sigma \iota s$ como a responsável pelo drama interior que vive; os que testemunham, porém, o seu estado débil e transtornado encaram-na como uma enfermidade, que a abundância de termos retirados do mundo da medicina ajuda a sublinhar. 
Em geral, o receptor não fica indiferente à visão ${ }^{5}$, circunstância marcada com frequência nos Poemas Homéricos por verbos dinâmicos que por vezes se acumulam, representativos da acção subsequente à experiência observada, por norma expressiva da aceitação da mensagem (cf. Il. 2. 4247, 50-52, 10. 513-514, 11. 211-213, Od. 6. 50, 14. 499-501, 15. 44-47). Por outro lado, o contacto entre o homem épico e o mundo divino, superior e inquestionável, é susceptível de causar aos efémeros ora surpresa e

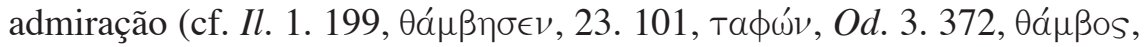

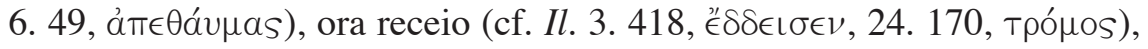

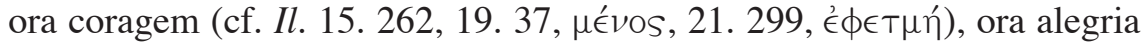

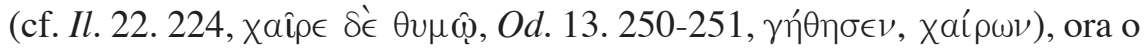
alívio e, paradoxalmente, o cepticismo de uma figura específica, Penélope: o relevo concedido pela Odisseia ao estado de alma desta personagem justifica de algum modo o efeito de descrença que os sonhos nela produzem, pouco comum na épica.

Admiração e respeito temeroso são sensações despoletadas pela percepção de uma luminosidade invulgar nas aparições com que os receptores dos Hinos Homéricos a Afrodite e a Deméter se deparam ( $h$. Hom. Aphr. 84 sqq.; h. Hom. Dem. 190).

Em Píndaro, as visões em estado de vigília surgem sobretudo como um meio de engrandecer determinados heróis, sem dúvida merecedores da tutela divina, pelo que a reacção a essas experiências se traduz seja na participação, honrosa para o receptor, na edificação dos muros de Tróia, em conjunto com os deuses (O.8.31 sqq.), seja pela exibição de uma atitude exemplar de partilha das benesses divinas ( N. 10. 89 sqq.). Por outro lado, a autoridade conferida aos sonhos enquanto sinais divinos cuja mensagem aparece confirmada por algum oráculo instiga os receptores a uma acção consonante com as indicações veiculadas, que se traduz no recurso a verbos dinâmicos (P. 4. 163-165, O. 13.72 sqq.), bem como a advérbios sugestivos da prontidão desejável no cumprimento da missão apontada pelo sonho $(P$. 4. 164, is táxos, O. 13. 79, тáxıбтa).

As visões herodotianas inspiram em geral uma actuação semelhante da parte dos receptores, que se mostram preocupados em seguir as

${ }^{5}$ Todavia, nas Histórias, quer Hiparco, quer Xerxes, diante do primeiro sonho que o perturba, mostram dar pouco crédito às visões sonhadas, como bem

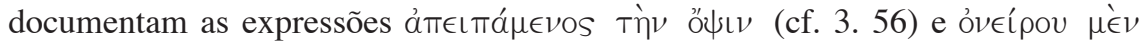

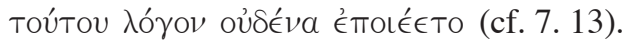


advertências das aparições $(4.15,5.92,6.105,8.84)$. Todavia, no que toca às experiências sonhadas, a realidade das Histórias distingue-se daquela perceptível na poesia homérica, mas assemelha-se bastante à da produção trágica: vocábulos relacionados com o temor resultante dos sonhos (cf.

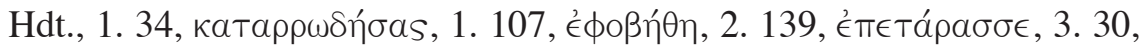
$\delta \in i ́ \sigma a s, 7.15, \pi \epsilon \rho \iota \delta \in$ ńs), ${ }^{6}$ bem como formas verbais no imperativo (Hdt.,

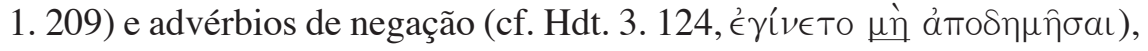
representativos da tentativa usual do receptor para evitar a realização do sonho, destacam-se repetidamente 7 . A reacção contra a experiência ocorrida durante o sono é também expressa por formas verbais indicadoras de movimentação da parte do sonhador, que pretende contrariar, em vão, os

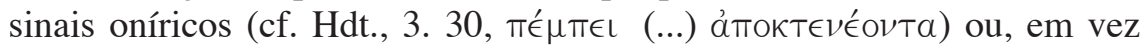

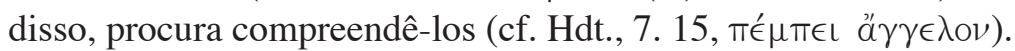

A pretensão de neutralizar experiências prenunciadoras de algo funesto ganha particular relevo nos sonhos trágicos femininos; todavia, se em Heródoto a resistência dos receptores, maioritariamente figuras masculinas, se traduz em actos do tipo "não mais enviar o filho como comandante dos Lídios' (1. 34), ou 'pôr sob vigilância a filha, que estava grávida' (1. 108), na produção dramática deparamo-nos sobretudo com a oposição de mulheres cuja angústia face à percepção, ainda que vaga, de um destino ominoso as conduz à execução de ritos purificadores. Tal comportamento recorrente justifica quer a frequência das alusões ao Sol ou ao dia luminoso, encarados como purgativos dos males anunciados (cf. S., El. 424-425, fr. 65 Radt; E., IT 43, Hec. 68), quer o recurso usual a uma linguagem associada a libações (cf. A., Pers. 201-204, Ch. 525, 538-539; S., El. 405-406, 431-434). Por outro lado, como acontece por hábito nas Histórias, também na tragédia ática se evidencia o temor e a angústia decorrentes da generalidade dos sonhos, mesmo se o entendimento deste fenómeno como um factor de satisfação não está ausente (e. g. E., I. 563-

${ }^{6}$ A épica regista também um verbo de receio, ${ }^{\prime} \delta \delta \in \iota \sigma \in \nu$, a propósito da reacção do velho Príamo ao sonho que o visita durante o sono (cf. Il. 24. 689); todavia, o receio do rei não o instiga a tentar anular o conteúdo da mensagem que lhe é transmitida, mas antes a procurar realizar de forma pronta as indicações sonhadas.

7 Pelo carácter excepcional dentro dos sonhos herodotianos, é digna de registo a serena confiança manifestada pelo faraó egípcio Seto na sua experiência

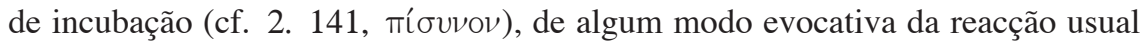
dos sonhadores épicos. 
565; IT. 452 sqq.): além de termos representativos daquelas sensações, por

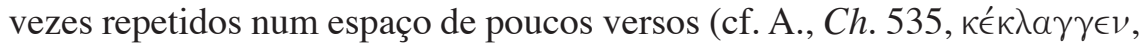

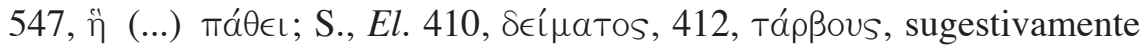

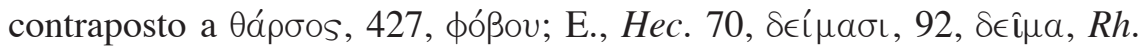
788, фóßos), interjeições de desespero (cf. A., Eu. 143; E., Rh. 798) e questões retóricas (cf. E., Hec. 68-70), expressas pelo próprio sonhador para imprimir maior vivacidade e realismo à sua experiência dolorosa, espelham de modo semelhante o pânico suscitado pela visão. Uma metáfora aliada a carros e aurigas que espicaçam os seus cavalos traduz de igual forma a costumada perturbação subsequente a tais experiências (cf. A., Eu. 155 sqq.).

Aristófanes, nas Vespas, caricatura o temor habitual das receptoras oníricas na tragédia, recorrendo para tal ao uso sugestivo da interjeição oĺ $\mu \mathrm{ol}$ (24), do nome какóv, apropriadamente associado a uma forma verbal no futuro, $\gamma \in \nu \eta \dot{\sigma} \in \operatorname{Tal}$ (24), e ainda de uma frase interrogativa (24-25).

A relação usual na produção trágica entre sonho e inquietação subsequente encontra paralelo nas visões em estado de vigília, em geral motivadoras também de uma agitação que a linguagem sugere de modo sintomático, quer através de vocabulário tradutor de perturbação e de desgraça, que concede especial relevo a termos cromáticos intensificadores do visualismo das cenas, e a verbos dinâmicos, significativos do tumulto experimentado (cf. A., Ag. 1082, 1137, 1216, 1293, 1309, Ch. 1049, 1053, 1058, 1062, Pr. 566; E., Tr. 325, 332-335, Ba. 1288), quer por meio de interjeições representativas da angústia dos receptores (cf. A., Ag. 1072, 1074, 1114, 1307, Ch. 1048, Pr. 566, 877; S., Aj. 333; E., HF 1146), quer ainda através de emotivas invocações e questões retóricas (cf. A., Ag. 1073, 1077, 1085-1086, 1100, 1114-1115, Ch. 1057; S., Aj. 339, 342-343; E., HF 1146-1150, Tr. 310, Ba.645-646, 1280). O recurso frequente à linguagem metafórica ilustra também o desassossego que domina as personagens, seja a menção à caça sem tréguas empreendida contra a infeliz Io (cf. A., $P r$. 573), ao delírio que arde no seu íntimo (cf. A., Pr. 880), às ondas duma odiosa desgraça com as quais os seus pensamentos se confrontam (cf. A., Pr. 886), à ondulação estimulada por uma tempestade que gira em redor de Ájax (cf. S., Aj. 351-352), à vaga que sacode os sentidos do desditoso Héracles (cf. E., HF 1091-1092), ou ao convite obstinado e irónico de Cassandra à dança e à entoação de um canto nupcial (cf. E., Tr. 325 sqq.). Curiosamente, os termos relativos ao medo, empregues de modo profícuo a propósito da reacção dos sonhadores, têm um destaque bem menor nas visões em estado 
de vigília, sendo apenas raras vezes referidos pelos receptores (cf. contudo A., $\operatorname{Pr} .568,881$ ), que acentuam sobremodo o sofrimento.

$\mathrm{Na} H e ́ c u b a$, a dor intensa da sonhadora reflecte-se também em termos discursivos, sublinhando o gosto de Eurípides pelo patético: com efeito, a angústia profunda da velha rainha de Tróia apenas no canto encontra um meio de ser extravasada, artifício parodiado de modo sintomático por Aristófanes em $R a .1331$ sqq. O facto de Hécuba descrever a experiência onírica numa monódia que a destaca em cena equivale a amplificar a agonia que sente: cantar o sonho torna-se mais impressivo do que narrá-lo. A par da melodia, denunciadora da emotividade descomedida de Hécuba, "a disposição astrófica, sem qualquer tipo de correspondência simétrica nas partes do canto, e a pluralidade de metros sobressaem"8 da caricatura do comediógrafo à monódia da debilitada rainha.

O canto liga-se ainda ao motivo do sonho nas Coéforas e nas Euménides, desta feita entoado pelos coros respectivos, naquela que é a sua forma habitual de expressão, ou seja, nenhuma das peças pretende realçar a tensão emocional de um sonhador específico através da monódia ${ }^{9}$. Nas Coéforas, a melodia do coro é entrecortada pelas falas de Orestes, num diálogo esticomítico revelador do vivo interesse do jovem em desvendar, em simultâneo, o conteúdo e o sentido do sonho materno (526-533).

O canto é também o modo de expressão eleito por Ésquilo e por Eurípides para dar voz a Cassandra, quando esta se faz ouvir pela primeira vez em cena, respectivamente no Agamémnon e nas Troianas, porquanto realça a tensão emotiva da vidente, sabedora do destino cruel que a aguarda, a si mesma e a alguns daqueles que a rodeiam. Contudo, se nas Troianas é a monódia que exibe com propriedade a emoção extraordinária da princesa, no Agamémnon a melodia é interrompida de forma insistente pelas palavras do coro, personagem de peso na produção esquiliana, e que nesta peça acaba por ir comentando a visão à medida que ela é descrita, aliás como acontece com a de Orestes nas Coéforas, mesmo se aí as imagens vistas pelo príncipe não são cantadas, mas antes narradas.

${ }^{8}$ M. F. Silva 1997: 286.

${ }^{9} \mathrm{O}$ uso da monódia parece claramente ter-se imposto na tragédia em época posterior a Ésquilo; segundo S. Barlow 1971: 43-60, a monódia foi sobremodo desenvolvida por Eurípides, para evidenciar as emoções extremas vividas pelas suas personagens. 
A "monódia epirremática"10 acompanha de modo adequado o enorme alvoroço de Io, quando aparece em cena no Prometeu, atormentada pela visão frequente de um tavão que a espicaça e a persegue sem cessar.

O canto mostra-se assim particularmente aliado a receptoras femininas de visões, em momentos de exteriorização, na primeira pessoa, de emoções muito dolorosas. No caso dos sonhos, a narração sobrepõe-se ao canto, mesmo se eles são revelados pelo próprio receptor onírico, como é costume acontecer (cf. Atossa, Io, Ifigénia, auriga de Reso): a angústia dos sonhadores é menos sublinhada a nível do tom escolhido para a descrição do que a nível vocabular ou imagético.

Nas visões em estado de vigília, a narrativa é sobretudo usada para uma personagem, distinta daquela que recebe as imagens, recriar os acontecimentos extra-cénicos, imprimindo-lhes uma perspectiva pessoal, não raro assinalada pela comoção (cf. os Mensageiros, no Héracles, na Ifigénia entre os Tauros e nas Bacantes; Tecmessa, no Ájax), ou em vez disso, para assinalar uma certa satisfação das divindades, que se assumem como responsáveis pela iniciativa das visões (cf. Atena, no Ájax, Dioniso, nas Bacantes).

O episódio do espectro de Dario, nos Persas, permite uma consulta singular à própria visão, expressa através de um diálogo esclarecedor entre

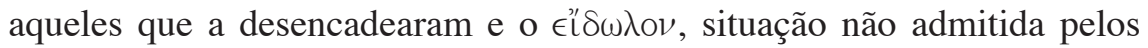
sonhos trágicos que conservamos.

O estado de letargia do receptor é o traço que estabelece de forma indiscutível a distinção entre o sonho e a visão em estado de vigília: o adormecimento nocturno é o momento privilegiado para a ocorrência dos sonhos, desde logo sugestivamente descritos por Hesíodo como filhos da noite e irmãos do sono ${ }^{11}$, circunstância que justifica a profusão de vocábulos

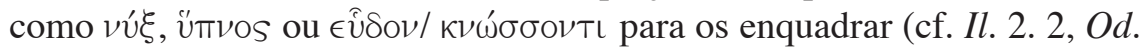
4. 493-494; Sapph., fr. 63 L.-P. 2; Pi., O. 13. 100-101; Hdt., 1. 209, 5. 56, 6. 10; E., Hec. 68; Ar., V. 12, Nu. 27). Este cenário reveste-se de particular significado na produção trágica, uma vez que permite acentuar a tonalidade obscura por norma associada àquele tipo de experiência nesse género literário, via de regra devido ao carácter pressago da mesma. Em contraste com o silêncio e a tranquilidade da noite e do sono aliviador de cuidados, a visão sonhada destaca-se assim como um meio de perturbação dos

${ }^{10}$ Sobre esta designação, cf. O. Pulquério 1965-1966: 35.

${ }^{11}$ Th. 211-212. 
receptores. Se o ambiente que envolve o sonho, por norma apenas suscita uma menção breve na lírica, na historiografia e na comédia, a épica insiste no quadro de acalmia que costuma anteceder a experiência (cf. Il. 23. 62$63,24.677-678$, Od. $4.493,20.83$ sqq.), ao passo que a tragédia realça com frequência os efeitos de uma visão desse tipo, seja através do recurso a questões retóricas (cf. E., Hec. 68-70) ou a invocações e preces desesperadas das personagens à Terra e aos deuses infernais (cf. A., Ch. 45; E., Hec. 70, 79), seja ao qualificar as trevas com epítetos tradutores da noção

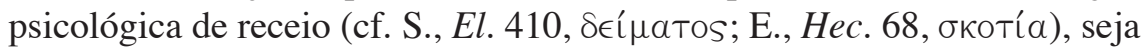
ao associá-las aos terrores da alma (cf. A., Ch. 523-524; E., Hec. 69-70), que podem manifestar-se através de gritos (A., Ch. 34-35).

A noite relaciona-se também, de forma explícita e expressiva, com uma visão em estado de vigília imaginada por Sófocles, claramente obscurecedora da ả $\rho \in T \eta ́$ de um herói, Ájax, e causadora da sua partida voluntária para o reino das sombras. Todavia, não é comum especificar-se o momento em que este género de experiência tem lugar, porque não é esse o traço que a define, mas antes o facto de ocorrer em ocasiões de vigia dos receptores, evidenciadas pela própria acção.

Paralelamente à heterogeneidade estética das experiências oníricas mencionadas no corpus de textos considerado, é interessante observar como a natureza frágil e fugidia do sonho, vincada pelos distintos géneros literários, acaba por servir de metáfora para explicitar outras situações da existência humana, onde as ideias de inconsistência e de fugacidade estão presentes, ilustrando uma interiorização das características mais salientes das visões sonhadas. Assim acontece logo na Ilíada, a propósito da perseguição de Aquiles a Heitor à volta dos muros de Tróia: desejoso de atingir de forma mortal o príncipe troiano, o Pelida não é todavia capaz de o apanhar, tal como quando num sonho quem persegue não alcança quem foge, mas nem um consegue fugir, nem o outro perseguir (Il. 22. 199-200) ${ }^{12}$.

O encontro de Ulisses com a $\psi v x \eta ́$ da mãe no Hades evidencia uma noção semelhante: no momento em que o filho de Laertes procura abraçar a saudosa Anticleia, a $\psi v \times \eta$ desta escorrega-lhe das mãos, como sombra ou sonho (Od. 11. 208). A cena proporciona ainda a comparação expressiva entre a alma dos mortos que, como um sonho, batendo as asas se evola

${ }^{12}$ F. Lourenço 2005: 437. Este passo suscitou imitações várias na literatura posterior (cf. M. Weidhorn 1967: 69-71. 
(Od. 11. 222) e a mobilidade que a épica homérica atribui por norma às aparições oníricas.

A proximidade entre a natureza débil e efémera dos sonhos e a vida humana nas suas distintas fases é repetidamente mencionada em comparações pela lírica (cf. Mimn., fr. 5; Thgn. 1020-1022, Pi., P. 8. 95-96), pela produção trágica (A., Pr. 545-550, Ag. 78-82, 1218; E., HF 111-112, Ph. $1545,1720-1722$, fr. $\left.25 \mathrm{~N}^{2}\right)$ e também pela comédia aristofânica, no seu habitual tom paródico (Av. 686).

Ésquilo assemelha ainda a existência dos mortais, antes das dádivas beneméritas do filantropo Prometeu, a uma outra característica usual das visões sonhadas, o seu carácter confuso (Pr. 448-450).

Deste modo, os sonhos são insistentemente tomados como termo de comparação para evidenciar uma perspectiva depreciativa da vida humana, frágil e fugaz como as experiências oníricas.

As visões, também elas dotadas de uma natureza fugidia e débil, prestam-se de igual forma a servir de elemento comparativo para realçar a precaridade da existência (E., $P h .1539$ sqq.). No entanto, tais características parecem ter ganho contornos estética e literariamente mais realçados pelos sonhos.

A necessidade, frequentemente sentida por receptores de sonhos e de visões em estado de vigília, de clarificar o conteúdo ambíguo das suas experiências, torna patente que aqueles fenómenos assumem, de modo progressivo, uma noção de desafio à percepção humana. $\mathrm{O}$ homem comum, porém, no pressuposto errado de que o conhecimento se constrói com base no primado dos sentidos, manifesta-se por norma incapaz de entender de forma devida a mensagem, fazendo uma leitura errada.

A acessibilidade do indivíduo a uma sabedoria não usual é causadora de perturbação, sendo de realçar a tendência evidenciada pelos receptores para contrariar o resultado das interpretações que fazem, ainda que em vão. 


\section{Bibliografia}

\section{Edições, traduções e comentários ${ }^{13}$}

Ferreira, J. R., Rocha Pereira, M. H., Silva, M. F. S. (1994), Heródoto. Histórias - Livro I. Lisboa: Edições 70.

Lourenço, F. (2005, $2^{\text {a }}$ ed.), Homero. Ilíada. Lisboa: Cotovia.

Mazon, P. (1986, 12 ${ }^{\mathrm{a}}$ ed.), Théogonie. Les travaux et les jours. Le bouclier. Paris: Les Belles Lettres.

Pulquério, M. O. (1998), Ésquilo. Oresteia. Lisboa: Edições 70.

Ruiz Garcia, E. (1989), Artemidoro. La interpretación de los sueños. Madrid: Editorial Gredos.

Russo, J. (coord.) (1985), Omero. Odissea - vol. 5 (libri 17-22). Milano: Fondazione Lorenzo Valla.

Sottomayor, A. P. Q. (1992), Ésquilo. Prometeu Agrilhoado. Lisboa: Edições 70.

\section{Estudos}

BARLOW, S. (2008, $3^{\mathrm{a}}$ ed.), The imagery of Euripides: a study in the dramatic use of pictorial language. London: Duckworth.

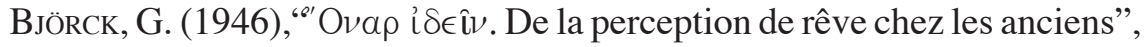
Eranos 44: 306-314.

Bouché-Leclerce, A. (2003), Histoire de la divination dans l'Antiquité. Grenoble: Éditions Jérôme Millon.

Branca, V., Ossola, C., Resnik, S. (1984), I linguaggi del sogno. Firenze: Sansoni Editori.

Bravo García, A. (1986), "La interpretación de los sueños: onirocrítica griega y analisis freudiana", in Rodríguez Alfageme, I., Bravo García, A. (eds.), Tradición clásica y siglo XX. Madrid: 124-141.

Corno, D. del (1982), "Dreams and their interpretation in ancient Greece", BICS 29: 55-62.

Crahay, R. (1956), La littérature oraculaire chez Hérodote. Paris: Les Belles Lettres.

Devereux, G. (1976), Dreams in Greek tragedy: an ethno-psycho-analytical study. Oxford: Blackwell.

${ }^{13}$ Referem-se sobretudo aos títulos citados/mencionados no presente artigo. 
Dodds, E. R. (1988), Os Gregos e o irracional (trad. Port.). Lisboa: Gradiva.

Dumortier, J. (1935), Les images dans la poésie d'Eschyle. Paris: Les Belles Lettres.

Flacelière, R. (1972, $3^{\text {a }}$ ed.), Devins et oracles grecs. Paris: P.U.F.

Guerreiro, C. A. (1998), Os sonhos régios da Pérsia nas Histórias de Heródoto. Dissertação de doutoramento em Literatura Grega, apresentada à Faculdade de Letras da Universidade de Lisboa (exemplar policopiado). Lisboa.

Guez, J.-Ph. (1999), "Du rêve homérique au rêve posthomérique", AC 68: 81-98.

Kessels, A. H. M. (1978), Studies on the dream in Greek literature. Utrecht: HES Publishers.

LÉvy, E.(1982), "Le rêve homérique", Ktema 7: 23-41.

LÉvy, E. (1983),"Le théâtre et le rêve: le rêve dans le théâtre d'Eschyle", in Zehnacker, H. (ed.) Théâtre et spectacles dans l'Antiquité - Actes du Colloque de Strasbourg. Leiden: 141-168.

Lieshout, R. G. A. Van (1980), Greeks on dreams. Utrecht: HES Publishers.

Porter, D. H. (1986), "The imagery of Greek tragedy: three characteristics", SO 61: 19-42.

PulquérIo, M. O. (1965-1966), "Estrutura e função do diálogo líricoepirremático em Ésquilo", Humanitas 17 e 18: 1-138.

RECKFORD, K. J. (1977), "Catharsis and dream interpretation in Aristophanes' Wasps", TAPhA 107: 283-312.

Seale, D. (1982), Vision and stagecraft in Sophocles. London: Croom Helm.

Segal, C. (1980) "Visual symbolism and visual effects in Sophocles", CW 74: $125-142$.

Silva, M. F. (1997, $2^{\text {a }}$ ed.), Crítica do teatro na comédia antiga. Coimbra: Fundação Calouste Gulbenkian, Junta Nacional de Investigação Científica e Tecnológica.

Taillardt, J. (1962), Les images d'Aristophane. Études de langue et de style. Paris: Les Belles Lettres.

WeIDHORn, M. (1967), "The anxiety dream in literature from Homer to Milton", SPh 64: 65-82. 